\title{
Contrasted effects of climate change on low-altitude relict Pinus uncinata stands in the Northern French Alps
}

\author{
Christophe Corona ${ }^{1,2} \cdot$ Markus Stoffel $^{2,3,4}(0)$ Jérôme Lopez Saez ${ }^{2}$
}

Received: 31 March 2021 / Accepted: 6 September 2021 / Published online: 3 October 2021

(c) The Author(s) 2021

\begin{abstract}
This paper reports on climate-induced growth changes in relict, low-altitude mountain pines (Pinus uncinata Mill. ex. Mirb.) from two refugia with cold microclimates located in the Northern French Alps. The P. uncinata stands analyzed grow at the lower bound of their ecological limit and are thus thought to be sensitive indicators of ongoing climate change. Using dendroecological approaches, we compare tree-ring growth at two closely spaced low-altitude stands in the Chartreuse massif (French Alps): La Plagne and Cirque de Bresson. La Plagne is a N-NW-exposed, ventilated slope with cold air circulating in the scree during summer, and the presence of sporadic permafrost as well as ground overcooling, whereas Cirque de Bresson is located on a small, S-exposed fan with sporadic avalanche activity. At both sites, growth responses of $P$. uncinata to changes in twentieth and twenty-first centuries temperature and precipitation conditions were investigated by means of moving correlation analyses. At Cirque de Bresson, a significant and rapid decline in tree-ring widths has been observed since the early 1990s. We attribute this decline to (i) increasing air temperatures at the beginning of the growing season (May-June) as well as to (ii) a decrease in soil water potential. At La Plagne, we do not detect any significant trend between the higher summer temperatures and tree growth, presumably as a result of the circulation of cold air in the scree slope, which is thought to maintain fresh and humid soil conditions and therefore favor tree growth. These forest stands provide prime examples on how dendroecology can contribute to the study of the dynamics and local variability of tree growth and climate change in relict forest populations with high ecological and conservation values.
\end{abstract}

Keywords Paleorefugia $\cdot$ Growth decline $\cdot$ Climate change $\cdot$ Tree ring $\cdot$ Dendroecology $\cdot$ Correlation functions $\cdot$ French Alps

\section{Introduction}

In the Northern French Alps, mountain pines (Pinus uncinata Mill. ex Mirb.) are typically at their optimum in the subalpine belt, at altitudes between 1600 and $2300 \mathrm{~m}$ a.s.l. (Rolland and Schueller 1995). At least seven P. uncinata

Responsible Editor: Mohamed Ksibi.

Christophe Corona

christophe.corona@uca.fr

1 Université Clermont-Auvergne, CNRS Geolab UMR 6042, 63057 Clermont-Ferrand, France

2 Climate Change Impacts and Risks in the Anthropocene (C-CIA), Institute for Environmental Sciences, University of Geneva, 1205 Geneva, Switzerland

3 Department of Earth Sciences, University of Geneva, 1205 Geneva, Switzerland

4 Department F.-A. Forel for Environmental and Aquatic Sciences, University of Geneva, 1205 Geneva, Switzerland stands have, however, been identified on cold scree slopes at abnormally low elevations (i.e., $1100-1450 \mathrm{~m}$ a.s.1.) in the Rhône-Alpes region. As a result of their abnormally low altitudinal position, these stands are thought to constitute natural areas of ecologic, faunistic, and floristic interest (Richard 1970).

The small-scale $P$. uncinata habitats are older than the surrounding biological matrix and therefore act as refugia by supporting communities that would be unable to survive elsewhere in the landscape. This means that the cold microclimatic conditions prevailing in these environments can support exceptional microhabitats with very thick raw 
humus (Cassagne et al. 2008), which typically favors the colonization of cold living plants (Bertinelli et al. 1993) and periglacial relict species of nonvascular plants (Asta et al. 2001), beetles (Molenda 1996), spiders (Ruzicka and Zacharda 1994), and mites (Zacharda et al. 2005). In the literature, these particular ecosystems were described as boreo-alpine enclaves (Cécillon 2009; Duret and Knutti 2008), islands (Gude et al. 2003), or abyssal (Bertinelli et al. 1993) or azonal (Rist et al. 2003; Morard 2011) ecosystems.

In terms of physical processes, cold scree slope ecosystems can be grouped into three categories. The first is related to shaded, $\mathrm{N}$-exposed slopes (typically with cirques or snowbed topographies) where total solar radiation is limited (Hoelzle and Haeberli 1995; Kneisel et al. 2000; Etzelmüller et al. 2001; Gadek 2012). At these sites, the ground thermal regime is controlled by the interaction of climatic conditions with topography (such as north exposure, limited amount of incoming solar radiation, shadow effect of mountains, frequent temperature inversions in winter, or distribution/duration of snow cover) as well as surface and subsurface factors (organic layers, blocky material, water supply in scree slope). In the French Alps, the P. uncinata stands of Cirque de Saint-Même (Chartreuse massif) and La Grande Aiguille (Oisans massif; Corona et al. 2015) show this setting. The second category of cold scree slopes is attributed to a process of reversible internal air circulation in scree slopes, also referred to as "chimney effect" or "wind tube" (Sawada et al. 2003; Morard et al. 2010; Stiegler et al. 2014; Kneisel et al. 2015; Wicky and Hauck 2017). Here, the circulation of air in the scree slope provokes strong ground overcooling and sometimes even favors the occurrence of low-altitude permafrost. At La Combe Obscure (Devoluy massif, Bertinelli et al. 1993), Bois du Sappey (Devoluy massif, Lambert 1967; Cécillon 2009), and La Plagne (Grande Chartreuse massif, Richard 1970; Cassagne et al. 2008), the existence of $P$. uncinata stands has been shown to be intimately related to the circulation of cold air in the scree slopes (Cécillon et al. 2010). The third category of cold scree slope ecosystems can be encountered on small, poorly functional snow avalanche cones with very limited avalanche activity. Such sites will maintain paraglacial, pedoclimatic conditions and can be found in the Saint-Même or Bresson cirques (Chartreuse massif) (Bertinelli et al. 1993).

Whereas the thermal mechanics of scree slopes have been investigated in great detail lately (Niu et al. 2016), the ecological properties of relict, low-altitude environments have been hardly studied so far (Cassagne et al. 2008; Kneisel et al. 2015; Meynier and Brun 2018). In addition, as P. uncinata stands growing in these refugia are located at the very lower bounds of their ecological limits, they are expected to represent sensitive indicators of climate change (Oberhuber et al. 2008). Moreover, in these open, low-production forests, species competition remains limited, and evidence of forest interventions is clearly lacking, such that growth changes in trees can be linked to changing climatic conditions. In this paper, we therefore hypothesize that low-altitude $P$. uncinata stands bear an imprint of the recent warming observed in the Alps since the 1990s (Hock et al. 2019).

The present study has been realized at two low-altitude $P$. uncinata stands of the Chartreuse massif (La Plagne, Cirque de Bresson). Based on the dendroecological record and growth patterns of these neighboring stands, we (i) determine high- to low-frequency wavelengths embedded in the annually resolved ring-width series; and (ii) use correlation analyses to assess growth responses of $P$. uncinata to changing temperature and precipitation.

\section{Materials and methods}

\section{Study site}

The study sites of La Plagne $\left(45^{\circ} 27^{\prime} \mathrm{N}, 5^{\circ} 55^{\prime} \mathrm{E}\right.$, $1200-1300 \mathrm{~m}$ a.s.1.) and Cirque de Bresson ( $45^{\circ} 25^{\prime} \mathrm{N}, 5^{\circ}$ $57^{\prime}$ E, $1200 \mathrm{~m}$ a.s.l.) are situated in the Northern French Alps (Fig. 1). The P. uncinata trees at La Plagne grow at the lower end of a N-NW-exposed, porous scree slope (mean slope angle $40^{\circ}$ ) composed of crushed, Urgonian limestone (Fig. 2a). Thermal conditions of the La Plagne scree slope are driven by a "chimney effect" (Meynier and Brun 2018),

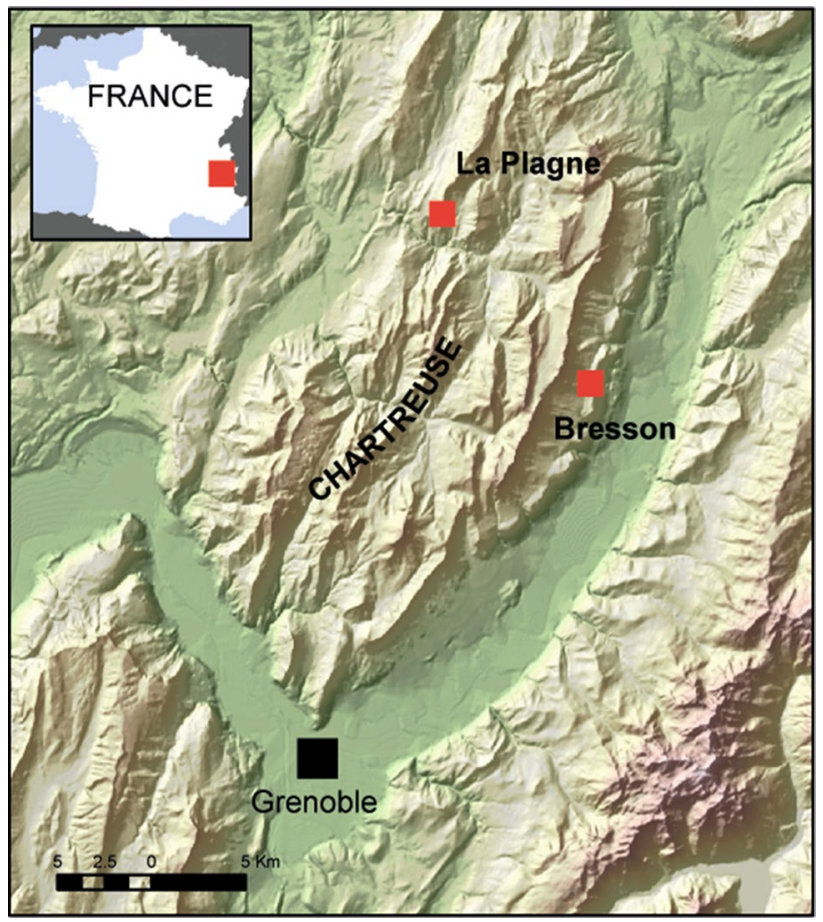

Fig. 1 Location of the study sites Cirque de Bresson and La Plagne in the Chartreuse massif (Northern French Alps) 


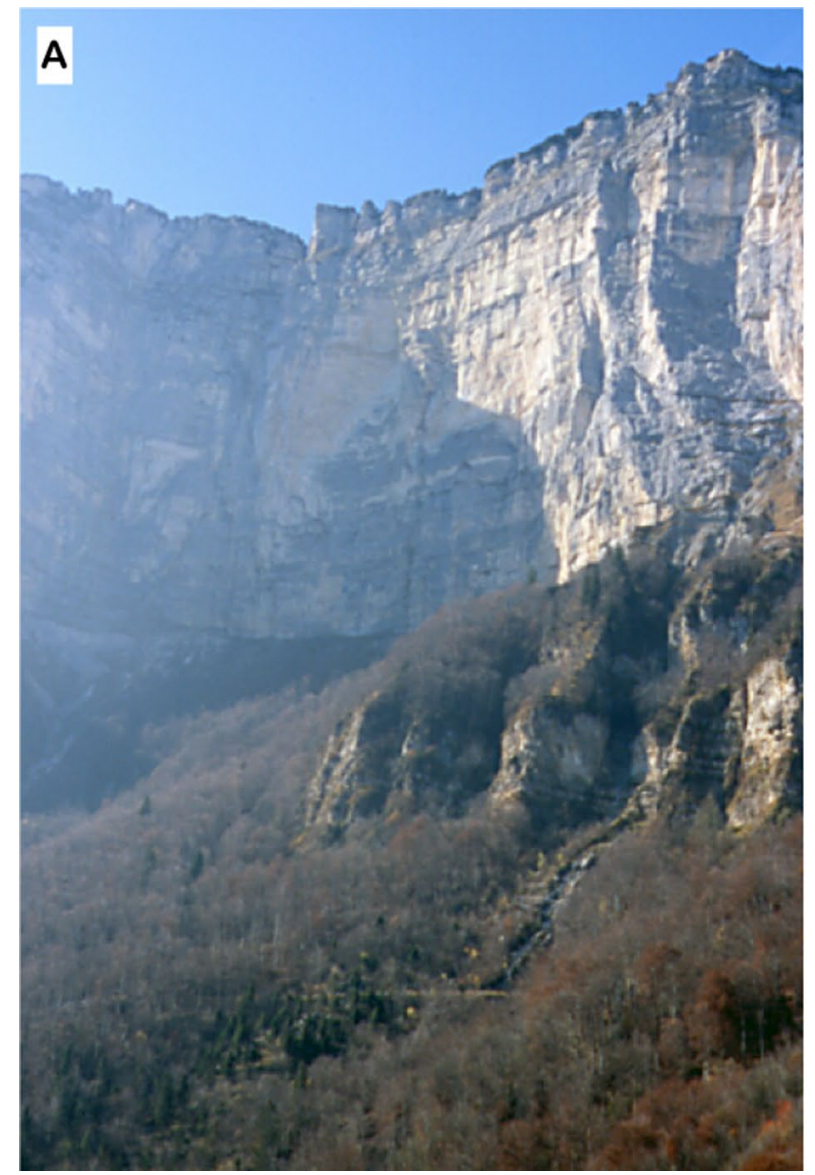

Fig. 2 The Cirque de Bresson site is located in a glacier cirque (a) on the eastern border of the Chartreuse massif and at the outlet of a inactive avalanche couloir (b). Exposed to the south-east, the forest stand is composed of $\sim 50 P$. uncinata surrounded with climactic

through which internal air circulation can support permanent ice lenses at altitudes far below the regular lower limit of permafrost (Kneisel et al. 2015). This chimney effect is driven by a strong thermal contrast between the scree slope (i.e., internal air) and the atmosphere (i.e., external air), resulting in a gradient of the driving pressure governing a seasonally reversible air circulation (Delaloye et al. 2003; Morard et al. 2010): during winter, the warmer internal air ascends through the upper part of the scree, leading to an aspiration of external cold air in its lower part (ascending air circulation). Inversely, during summer, denser cold air is discharging at the foot of the scree slope, thereby cooling down the bottom part of the system. Consequently, the cold airflow generates a diffuse aspiration of warmer external air in the upper part of the scree slope (descending air circulation) (Meynier and Brun 2018).

The Cirque de Bresson site (Fig. 3a) is located in a glacier cirque on the eastern border of the Chartreuse massif and at the outlet of a mostly inactive avalanche couloir (Fig. 3b). With exposure to the south-east, the corridor carves an

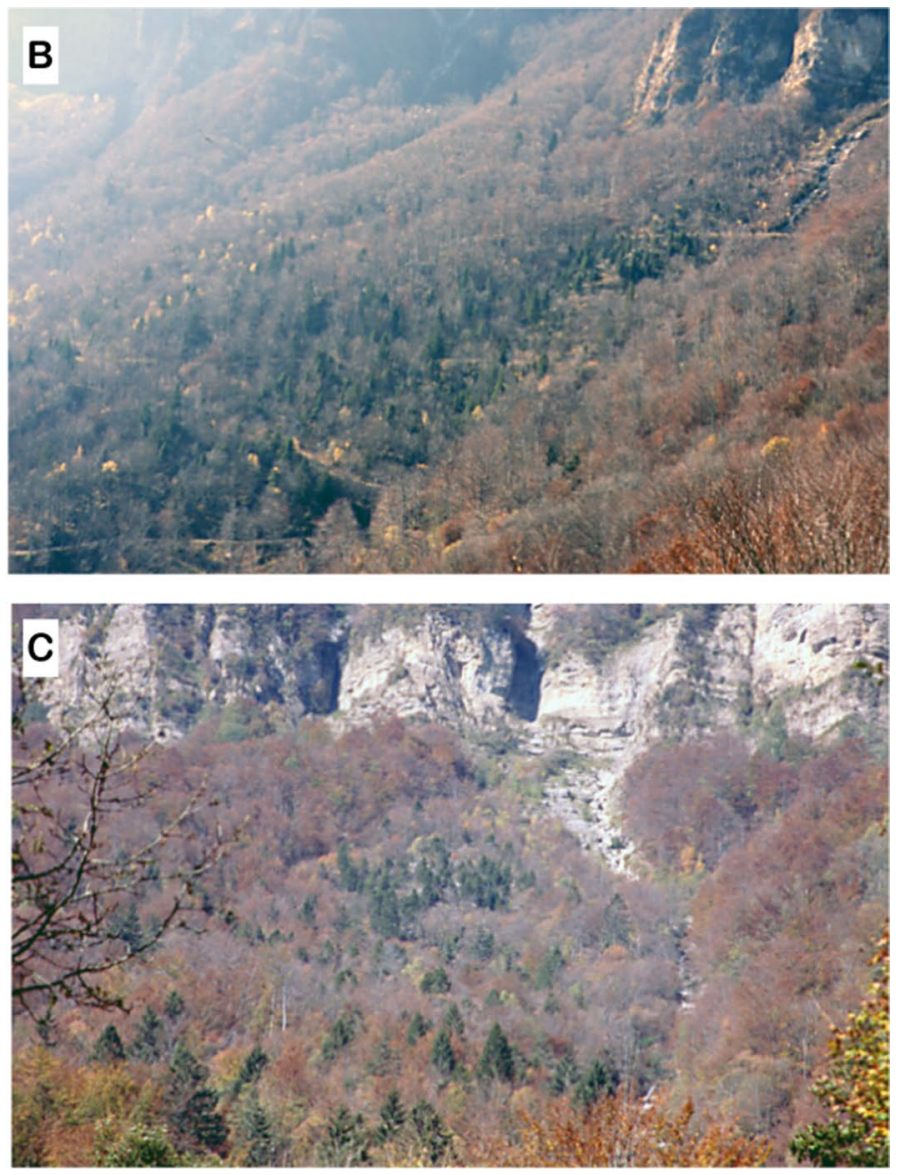

Picea abies and beech-fir forests (Fagus sylvatica, Abies alba), in association with more thermophilic species (Acer opalus, Laburnum anagyroides) (c)

Urgonian limestone cliff between 1300 and $1850 \mathrm{~m}$ a.s.1. The avalanche cone has a slope of about $25^{\circ}$ and is exposed S-SW. Based on repeat observations at different seasons, no chimney effect can be discerned at Cirque de Bresson.

Both sites can be described as cold alpine enclaves in a montane ecosystem dominated by $P$. uncinata forests and are surrounded by a climactic Norway spruce (Picea abies)-silver fir (Abies alba) forest at La Plagne, and by a $P$. abies and beech-fir forests (Fagus sylvatica, A. alba) at Cirque de Bresson. At the latter site, more thermophilic species (such as Acer opalus or Laburnum anagyroides) can be found as well (Fig. 3c). Soil and humus formation is driven by sitespecific properties of bedrock and internal thermal conditions rather than vegetation; soils are identified as histosols according to USDA Soil Taxonomy (USDA 1999) and characterized by thick raw Tangel humus (Meynier and Brun 2018).

The heterogeneous abiotic conditions prevailing at either site result in an ecological mosaic composed of various communities of bryophytes, ericaceous shrubs, and lichens. In 

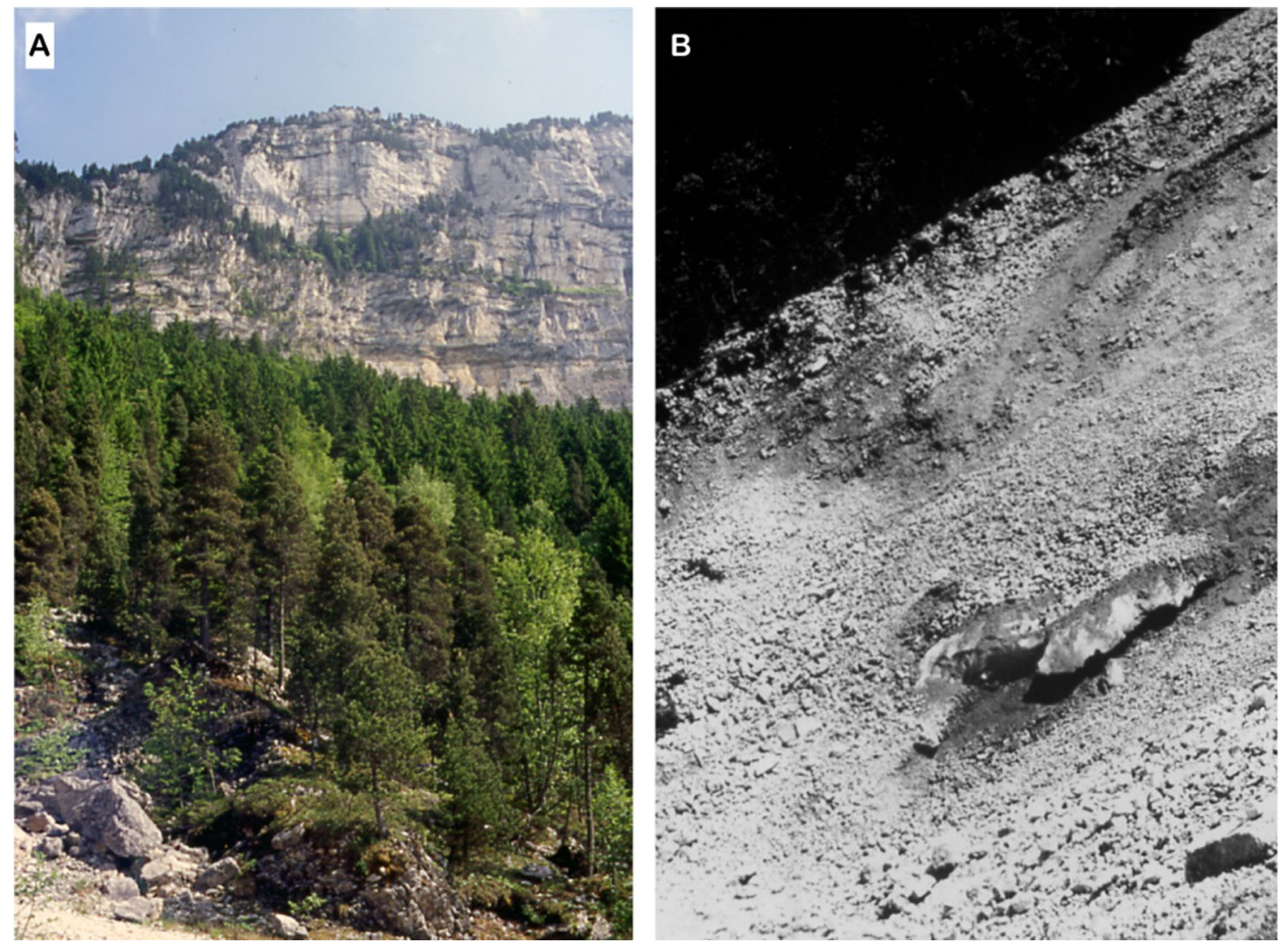

Fig. 3 The La Plagne pine stand is located at the lower end of a N-NW-exposed limestone scree slope (a). Advective heat fluxes exist in this porous talus slope, with associated cold air flows blowing out of the ground in summertime, and the presence of sporadic permafrost (b)

the case of La Plagne, ground flora consists of plants that are characteristic of raw humus (Rhododendron ferrugineum L., Vaccinium vitis-idaea L., V. myrtillus L.), with an important cover of mosses (Hylocomium splendens (Hedw.) B.,S.\&G., Rhytidiadelphus squarrosus (Hedw.) Warnst., Pleurozium schreberi (Brid.) Mitt., Dicranum scoparium Hedw., Polytrichum formosum Hedw.) and lichens (Cladonia rangiferina (L.) Web., C. gracilis (L.) Willd., Cetraria islandica (L.) Ach.). Alpine calciphilic species (Dryas octopetala L., Saxifraga oppositifolia L., Carex sempervirens Villars or Arctostaphylos uva-ursi (L.) Spreng.) can be found at both La Plagne and Cirque de Bresson.

Meteorological data were retrieved from the Saint-Pierrede-Chartreuse $\left(45^{\circ} 21^{\prime} \mathrm{N}, 5^{\circ} 47^{\prime}, 954 \mathrm{~m}\right)$ weather station located $6 \mathrm{~km}$ south of La Plagne and $10 \mathrm{~km}$ southwest of Cirque de Bresson. Mean monthly values calculated for the period 1950-2006 describe a humid climate with mean annual precipitation of $2053 \pm 322 \mathrm{~mm}$. Whereas dry conditions prevail in July and August, we observe precipitation maxima in autumn and a snow cover persisting on the ground from November to April. Mean annual air temperature at Saint-Pierre-de-Chartreuse for the same period is $7{ }^{\circ} \mathrm{C}$, and frost occurs on 96 days per year on average.

\section{Field collection and sample preparation}

To obtain tree-ring chronologies from both sites, we sampled 60 trees lacking obvious signs of stem or crown anomalies induced by lightning, wind, or snow breakage with an increment borer (i.e., two cores per tree for 120 increment cores in total). In the lab, samples were processed following standard dendroecological procedures (Bräker 2002), including sample mounting, drying, and surface preparation by finely sanding up to grit size 600. Tree rings were counted, and ring widths measured to the nearest $0.01 \mathrm{~mm}$ using a digital LINTAB positioning table connected to a Leica stereomicroscope and TSAP-Win Scientific software (Rinn 2003).

\section{Chronology development and statistics}

Prior to detrending, all ring width series were screened for missing rings and dating errors using COFECHA (Cook and Holmes 1984). To compare the chronologies, several descriptive statistics were computed with ARSTAN (Cook 1985); these included standard deviation (SD) to estimate variability of measurements for the whole series and mean sensitivity (MS) to represent the mean of relative deviations 
between consecutive rings for a given tree (Fritts 1976). Both SD and MS allow assessment of high-frequency variations in the chronologies. First-order serial autocorrelation (AC) was computed to detect any persistence retained in the chronologies, i.e., the influence of previous year growth on current year growth. To assess the reliability of each treering width chronology, we also calculated the expressed population signal (EPS); the limit at which tree-ring width chronologies were considered as reliable and well replicated was set to the commonly accepted threshold of 0.85 (Wigley et al. 1984). Mean correlation between trees ( $r$ bt) was calculated as the mean between all overlapping pairs of index series of trees.

Two conceptually different standardization approaches were used in this study, namely (i) the individual series standardization (Cook and Peters 1981, hereafter referred to as spline detrending) and (ii) the adaptative regional growth curve standardization (ARGC, Nicault et al. 2010; Shi et al. 2020). The two standardization methods are described in the following:

(i) Spline detrending: To remove the tree-ring trend in the series resulting from the tree circumference increasing with time, on the one hand, and to enhance interannual variations, on the other hand, individual series were first standardized by fitting a negative exponential curve to raw data series and by dividing observed with expected values. A spline function with a $50 \%$ frequency response of 20 years was then fitted to individual indexed series, and the observed/ expected ratio was computed again. This spline curve is sufficiently flexible to remove both mid-frequency variations related to disturbance pulses and longterm trends in tree-ring series (Cook and Peters 1981; Cook and Kairiukstis 1990). Finally, this process creates stationary time series for each tree with a mean of 1 and a homogeneous variance. The result of this approach is a unitless index of radial tree growth for each chronology.

(ii) Adaptative regional growth curve standardization: To preserve potential low-frequency climate variability and to avoid the "segment length curse" in tree-ring chronology development (Cook et al. 1995), the ARGC standardization (Nicault et al. 2010) was employed. This method is a refinement of the regional curve standardization (RCS; Briffa et al. 1992; Esper et al. 2002; Melvin et al. 2007) to individual trees and can take account of differences of cambial age and mean productivity as functions of competition and soil (Rathgeber et al. 2000). Here, tree-ring series are standardized into relative tree- ring indices through a division of each measured ring by its expected value estimated from a growth trend (Eq. 1). An artificial neural network (ANN) was then used to estimate the ARGC for each tree from cambial age, initial, and maximum tree productivity (Eq. 2). This nonlinear technique has been applied widely in dendroclimatology (Guiot and Tessier 1997). An ANN consists of a number of simple and interconnected processors called neurons. The signal from input variables goes through these neurons to become output variables. Interconnections are defined by coefficients that are adjusted to fit output variables best. The process of coefficient estimation (i.e., "training") needs hundreds of iterations. Any increase in the number of coefficients/iterations will thus introduce more nonlinearity to the system but also potentially more chaos. Therefore, a compromise has to be found between the best fit and a conservative predictability (Nicault et al. 2010). Based on the above considerations, we used a feed-forward network trained with the error back-propagation learning algorithm (Rumelhart et al. 1986). Input and output data were standardized between 0 and 1 before ANN training (Nicault et al. 2010). We did so by subtracting the minimum value and dividing by the range of values. In addition, we used three neurons in a hidden layer and a maximum of 5000 iterations. Productivity is taken into account on the basis of juvenile growth characteristics, and indexed series are obtained as follows:

$\mathrm{It}=\mathrm{Ct} / \mathrm{Yt}$,

$\mathrm{Yt}=F(\alpha(\mathrm{Ct}), g(C), G(C))$,

where $\mathrm{Ct}$ is the measured width of a tree ring, $\mathrm{Yt}$ is the theoretical value for tree ring $\mathrm{Ct}, \alpha(\mathrm{Ct})$ is the age of tree ring $\mathrm{Ct}$, and $g(C)$ is the initial growth of tree $C$ (i.e., the average of the first ten rings). To replace a missing year for any given tree ring, $G(C)$ is the maximum juvenile growth of tree $C$ (i.e., the maximum value reached during its juvenile stage (first 50 years) after smoothing with a 10-year window). As the ANN fits each tree, the detrending is not sensitive to the occurrence of missing rings at tree pith (Nicault et al. 2010). The approach has been shown to be particularly well suited to heterogeneous environments, such as Alpine regions (Corona et al. 2010) where rapid variations in soil conditions, microclimate, competition, and other factors governing site productivity may lead to major variations in tree growth rates. 


\section{Climate datasets}

Long meteorological series are critically lacking in the French Alps (Saulnier et al. 2011). As a result, records of temperature and precipitation from the HISTALP database (Auer et al. 2007) are used to study climate-growth relationships. This dataset is based on 192 precipitation and 132 temperature time series from a network of meteorological stations gridded on $0.1 \times 0.1^{\circ}$ and $1 \times 1^{\circ}$ lat/long networks, respectively. The dataset extends back to $\mathrm{AD} 1760$ and covers the Greater Alpine Region (GAR, $4-19^{\circ} \mathrm{E}, 43-49^{\circ} \mathrm{N}$, 0-3500 m a.s.1.); data are expressed as deviations from the 1961-1990 mean. For temperature, we used the latest version of the database, adjusted to take account of the warm bias in summer temperature related to the insufficient sheltering of thermometers before AD 1850 (Böhm et al. 2010).

To calibrate the response function and in view of the high climate variability in the Alps, especially in terms of precipitation, mean monthly series were calculated for temperature and precipitation from the four HISTALP point values enclosing the two $P$. uncinata stands under investigation $\left(5-6^{\circ} \mathrm{E}, 45-46^{\circ} \mathrm{N}\right.$ for temperature; $5^{\circ} 55^{\prime}-6^{\circ} 05^{\prime} \mathrm{E}$; $44^{\circ} 15^{\prime}-45^{\circ} 25^{\prime} \mathrm{N}$ for precipitation). Pearson's correlation analysis with the Saint-Pierre de Chartreuse meteorological series reveals highly significant coefficients for the overlapping time interval (1951-2007) (Fig. 4) varying between
January

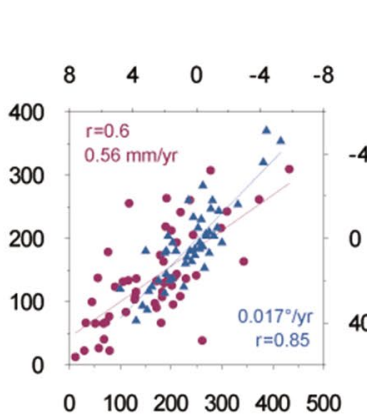

February

March

April

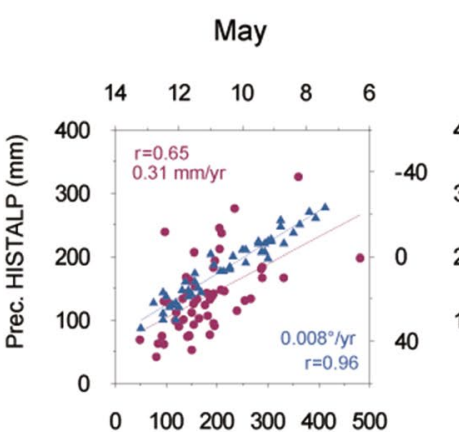

September

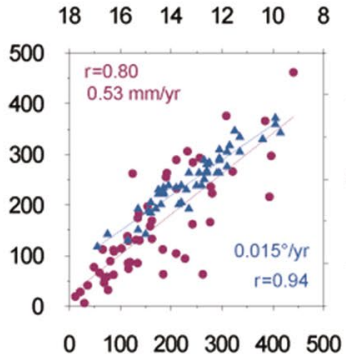

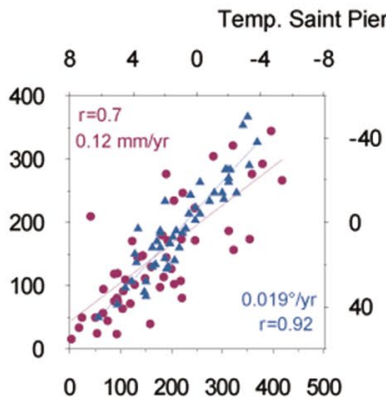

June

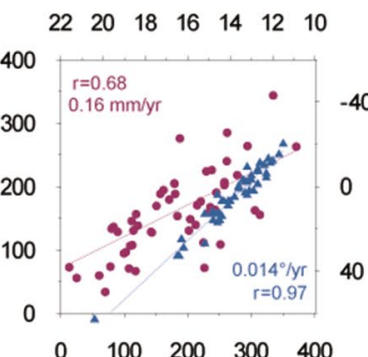

October

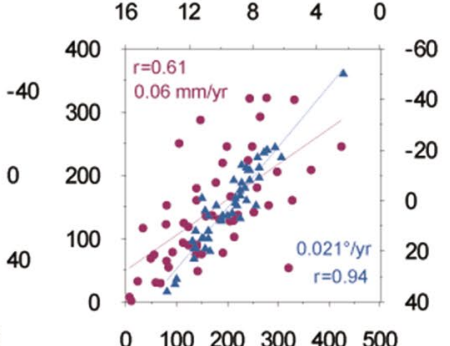

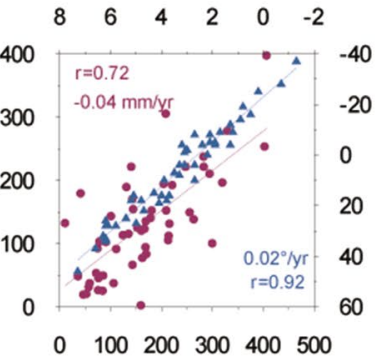

July

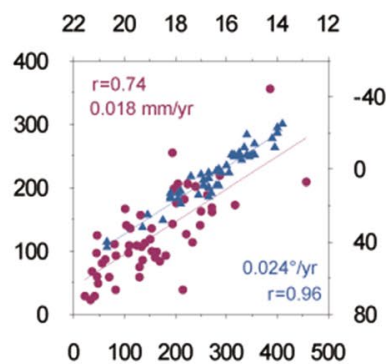

November

$\begin{array}{lllllll}10 & 8 & 6 & 4 & 2 & 0 & -2\end{array}$

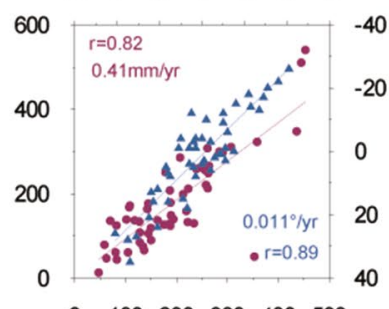

$0 \quad 100 \quad 200 \quad 300 \quad 400500$

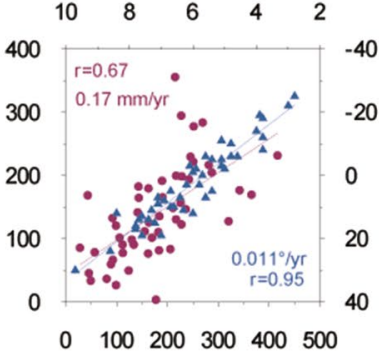

August

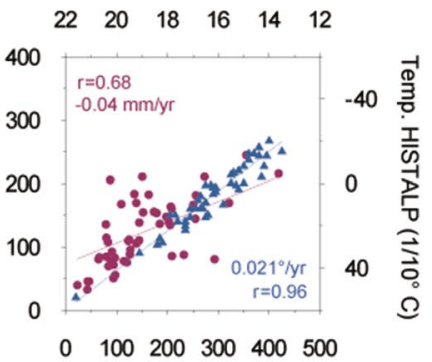

December

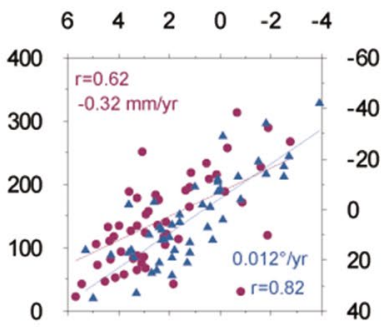

$0 \quad 100 \quad 200300 \quad 400500$

Prec. Saint Pierre de Chartreuse ( $\mathrm{mm})$

Fig. 4 Correlation between mean monthly series calculated for temperature and precipitation from four HISTALP point values enclosing the study sites and the Saint-Pierre de Chartreuse meteorological series within the overlapping time interval (1951-2007). All values are significant at $p<0.05 . \beta$ and $\alpha$ indicate regression line calculated for monthly temperature and precipitation series from the HISTALP dataset over the 1837-2007 period 
0.82 and 0.97 for temperature and 0.61 and 0.82 for precipitation, meaning that the HISTALP dataset represents local conditions well and can be used to compute climate-growth relationships at longer timescales.

\section{Climate-growth relationships}

For each chronology, years with positive or negative indices $\geq 1.5$ times above or below average in the spline detrended chronologies were categorized as extremes. These "extreme years" were then compared with records of temperature and precipitation from the HISTALP database for the period extending from previous $(t-1)$ May to current $(t)$ September, with previous and present referring to the growing season of trees which locally lasts from May to October.

Climate-growth correlations functions $(\mathrm{CF})$ between spline detrended chronologies and monthly climate predictors were computed for La Plagne and Cirque de Bresson for the period 1905-2008. The Dendroclim2002 software (Biondi and Waikul 2004) was used for this purpose, and median correlation coefficients were obtained with 1000 bootstrapped iterations.

The HISTALP dataset included mean monthly air temperature $\left({ }^{\circ} \mathrm{C}\right)$ and total monthly precipitation $(\mathrm{mm})$ sequenced from May of the year preceding growth-ring formation $(t-1)$ to September of the year of growth $(t)$, and thus consisted of 34 predictors. Computation of climate-growth relationships beyond the period of tree-ring formation was motivated by the fact that the width of an annual ring integrates climatically influenced processes occurring over longer periods (Fritts 1976).

To evaluate stationarity and consistency of correlations over time, we computed moving correlation functions (MCF) by progressively shifting the period of a fixed number of years across time to compute correlation coefficients (Oberhuber 2004). We did so by using DendroClim 2002 for moving spans of 50 years.

\section{Results}

\section{Analysis of climate data}

Annual mean temperature in the study area shows a clear increase over the past decades (Fig. 4) with statistically significant positive tendencies for each month and maximum in July $\left(0.024{ }^{\circ} \mathrm{C}\right.$ year $\left.{ }^{-1}\right)$, August, October $\left(0.021{ }^{\circ} \mathrm{C}_{\text {year }}{ }^{-1}\right)$, and March $\left(0.02{ }^{\circ} \mathrm{C}_{\text {year }}{ }^{-1}\right)$. The increase is weaker at the start of the growing season (April-June). Poorly significant trends are observed for annual precipitation over the period 1837-2007. Changes are most obvious for January $\left(0.56 \mathrm{~mm}\right.$ year $\left.^{-1}\right)$, September $\left(0.26 \mathrm{~mm}_{\text {year }}{ }^{-1}\right)$, and November $\left(0.41 \mathrm{~mm}\right.$ year $\left.^{-1}\right)$.

\section{Tree-ring chronology descriptive statistics}

The $P$. uncinata chronologies (minimum replication of five trees) of the La Plagne and Cirque de Bresson sites span 106 (1905-2010) and 126 years (1883-2008; Table 1), respectively, with the oldest trees at each site going back to 1873 (Fig. 5a) at Cirque de Bresson and 1859 (Fig. 6a) at La Plagne. High first-order autocorrelation (i.e., 0.67 at $\mathrm{La}$ Plagne and 0.61 at Bresson; Table 1) points to a strong influence of radial growth by conditions in the year preceding ring formation at La Plagne. The influence of climatic conditions in year $t-1$ on tree growth in year $t$ is much weaker at Cirque de Bresson, thus suggesting that the Cirque de Bresson tree population would be driven by a more "opportunistic" behavior and respond more rapidly to climatic variations as compared with La Plagne. The trees sampled at La Plagne exhibit more inertia and over longer periods, and thus show very little interannual variation in tree growth. Mean sensitivities of the two populations reveal only small differences (i.e., 0.19 and 0.25 at La Plagne and at Cirque de Bresson, respectively), with slightly higher maximum mean sensitivity values for the Cirque de Bresson population, thus pointing to slightly more marked sensitivity to climate variability. The chronologies exceed the EPS threshold of 0.85 over the period 1905-2010 at La Plagne and 1883-2008 at Cirque de Bresson, indicating the robustness of both site chronologies over these periods.

\section{Climate during extreme years}

Spline detrended ring-width chronologies are depicted in Figs. 5a and 6a. For each of the chronologies, years with positive/negative indices $\geq 1.5$ times above/below average (fixed to zero after detrending) were considered extremes and compared with meteorological records of the HISTALP database. The Cirque de Bresson population shows negative extremes in 1906, 1931, 1937, 1953, 1960, and 1990

Table 1 Summary information of the tree-ring width chronologies from La Plagne and Cirque de Bresson

\begin{tabular}{lll}
\hline Chronology statistics & La Plagne & Bresson \\
\hline Chronology length (span) & $1859-2010(1905-2010)$ & $\begin{array}{c}1873-2008 \\
(1883-\end{array}$ \\
& & $2008)$ \\
No. of trees (radii) & $21(42)$ & $18(36)$ \\
Ring width (1/100 mm) & $105(\mathrm{sd}=30)$ & $67(\mathrm{sd}=35)$ \\
Mean inter-series correlation & 0.44 & 0.41 \\
Mean sensitivity & 0.19 & 0.25 \\
Expressed population signal & 0.91 & 0.88 \\
Autocorrelation (AC1) & 0.67 & 0.61 \\
\hline
\end{tabular}

Information refers to raw ring widths before detrending ACl first-order serial autocorrelation 

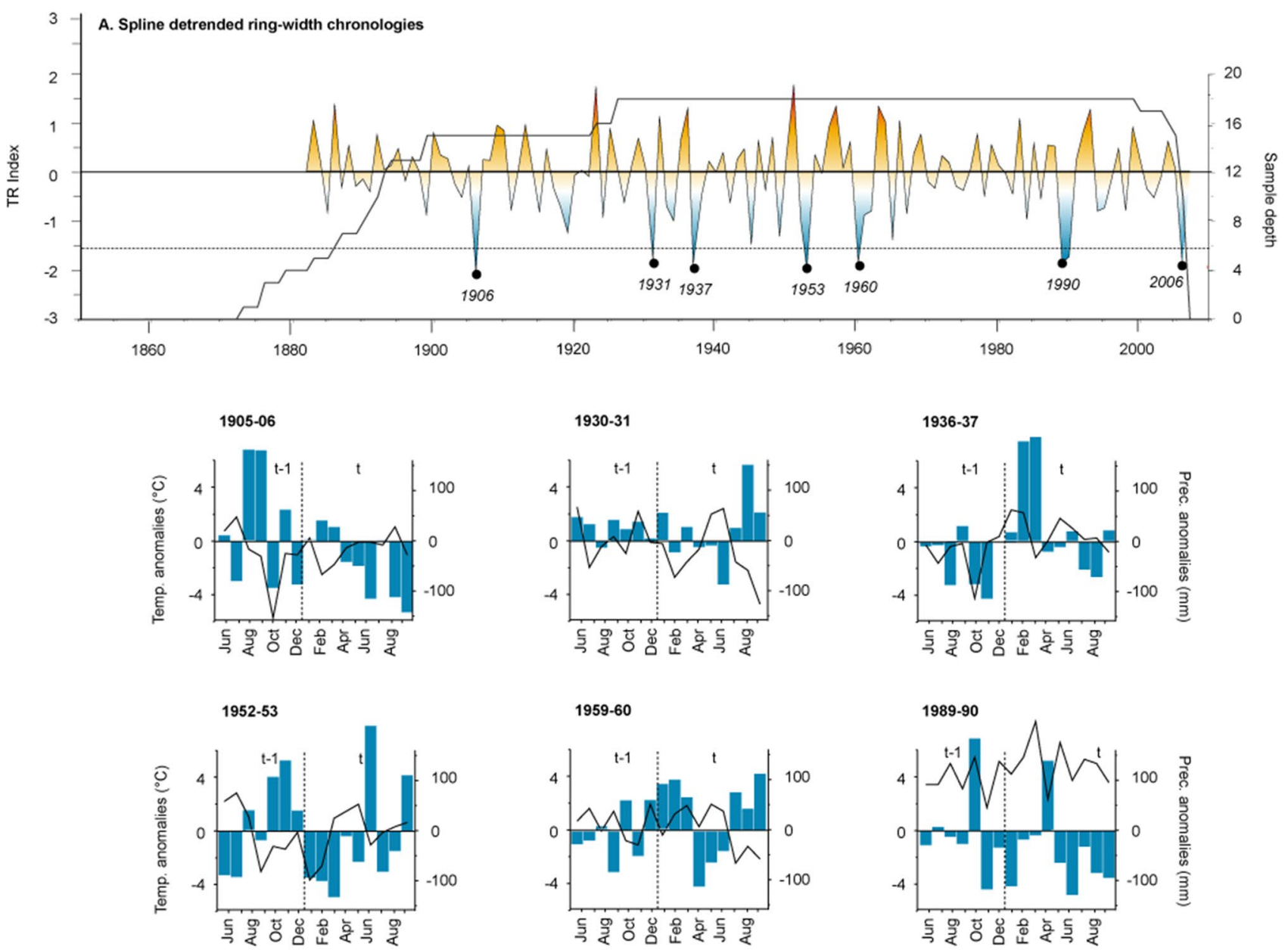

Fig. 5 Spline detrended chronology of Pinus uncinata from the Cirque de Bresson stand (a) and climatic diagrams of the negative extreme years (in red, b). Sample depth (number of trees included in chronologies) is emphasized with the gray area

(Fig. 5b). When compared with the HISTALP database, it becomes obvious that most of these extremes are characterized by below-average precipitation totals at the beginning of the growing season (in April, May, and June of year $t$, in particular). By way of example, low precipitation sums were particularly visible in 1990 (MJ: $-214 \mathrm{~mm}), 1906$ (MJ: -156 mm, AMJ: -199 mm), 1960 (AMJ: -204 mm), and 1931 (AMJ: $-105 \mathrm{~mm}$ ). For the years 1931, 1937, 1953, 1960, and 1990, the effect of dry conditions was enhanced further by above-average air temperatures between April and June, therefore favoring the occurrence of drought conditions.

The La Plagne population exhibits extreme negative years in 1886, 1894, 1911, 1941, 1954, and 2006 (Fig. 6b). These years are characterized by below-average precipitation totals in years $t-1$ and year $t(-615 \mathrm{~mm}$ between June 1940 and September 1941;-414 mm between June 1893 and September 1894; -255 mm between June 1885 and September 1886) or by below-average temperatures in June and July of year $t\left(-0.8{ }^{\circ} \mathrm{C}\right.$ in 1886 and $1894,-1{ }^{\circ} \mathrm{C}$ in 1954).
By contrast, the wide rings found in 1899, 1913, 1923, 1964, 1982, and 2001 (Fig. 6c) cannot be explained easily by monthly climatic anomalies as most of these years show neither anomalous temperature nor precipitation conditions.

\section{Monthly climate correlation}

The CF coefficients differ greatly between the Cirque de Bresson (Fig. 7a) and La Plagne (Fig. 8a) populations. At Cirque de Bresson, responses are dominated by positive correlations between ring widths and precipitation totals in May and June of year $t$. For the same period, strong negative correlations are also evident between temperatures and radial growth of $P$. uncinata. Results thus suggest a strong relation between tree-ring width and dry conditions at the beginning of the growing season of year $t$. The CF profiles further provide evidence that summer temperature (July, August) and spring precipitation (May) are the dominant factors controlling tree-ring width at La Plagne. Radial growth also seems 
B. Extreme positive years

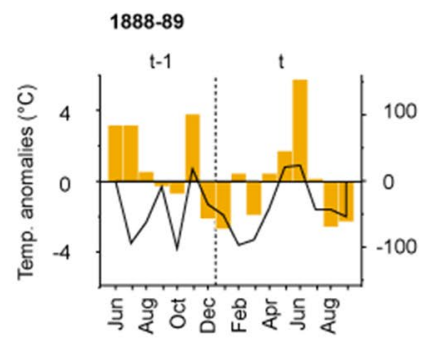

1963-64

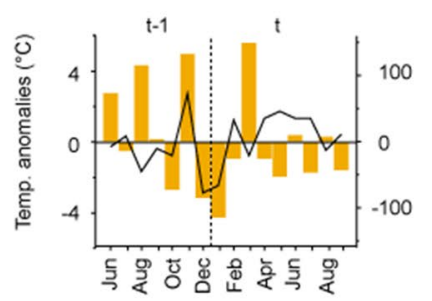

$1912-13$
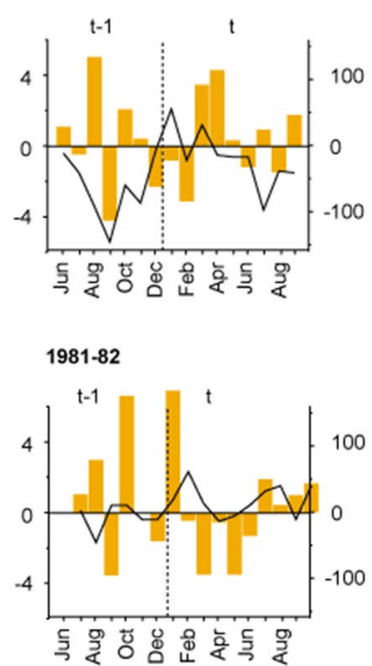

$1922-23$
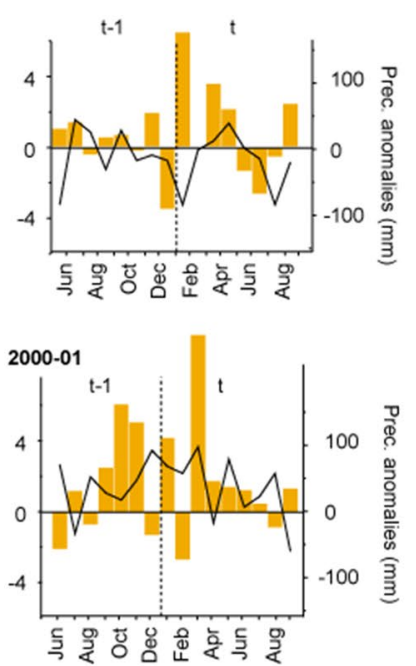

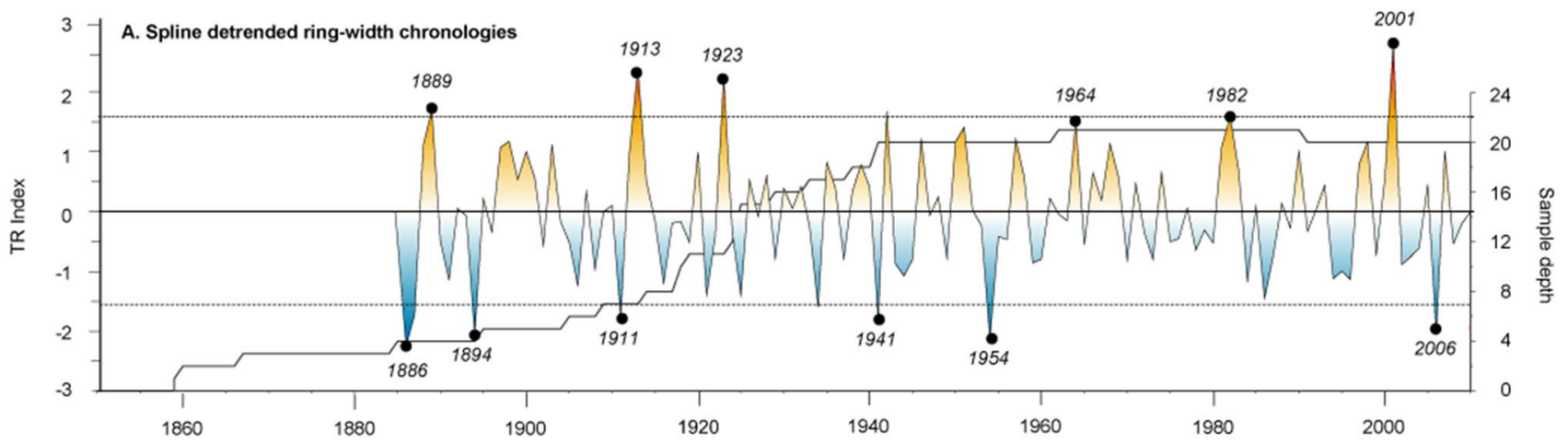

C. Extreme negative years
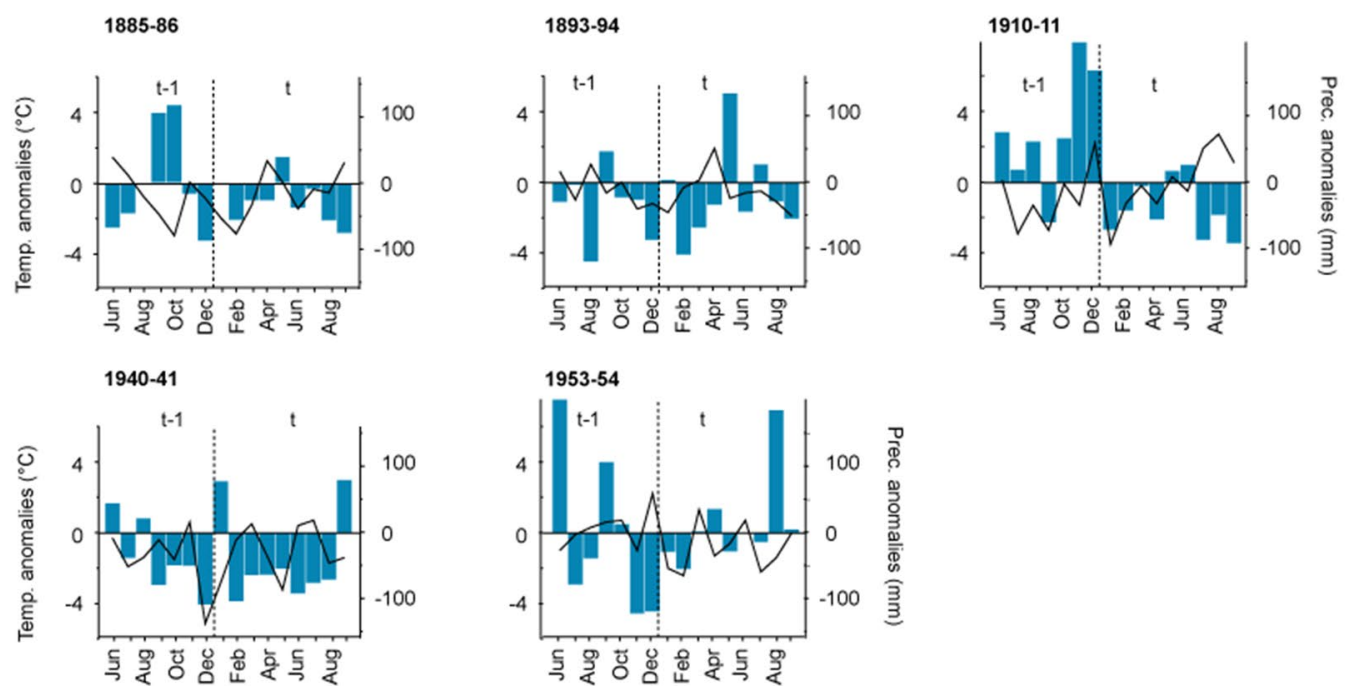

Fig. 6 Spline detrended chronology of Pinus uncinata from the La Plagne stand (a) and climatic diagrams of the negative (in red, b) and positive (in blue, c) extreme years. Sample depth (number of trees included in chronologies) is emphasized with the gray area 


\section{A Monthly temperatures}

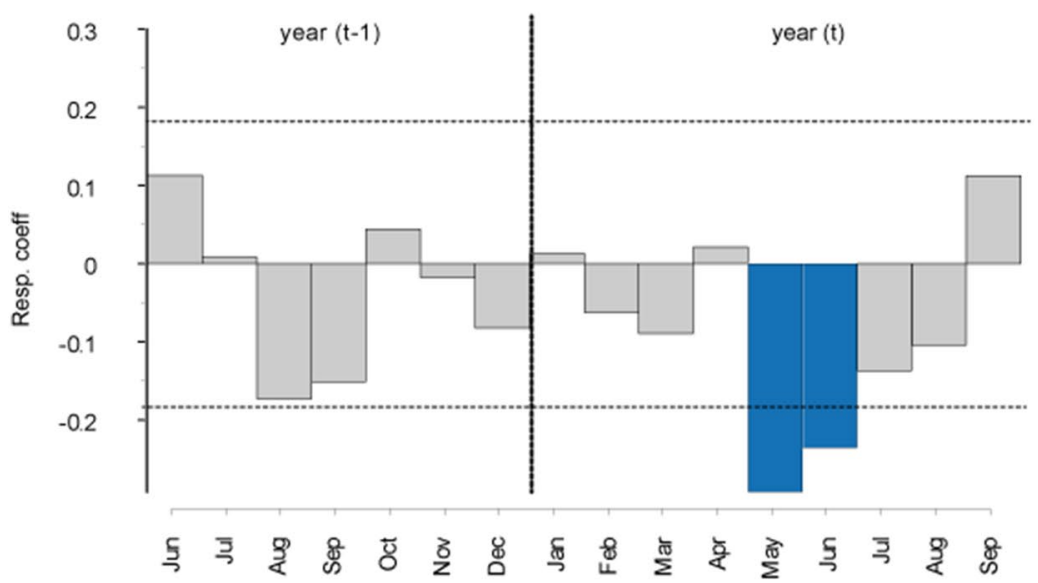

\section{B Monthly precipitation}

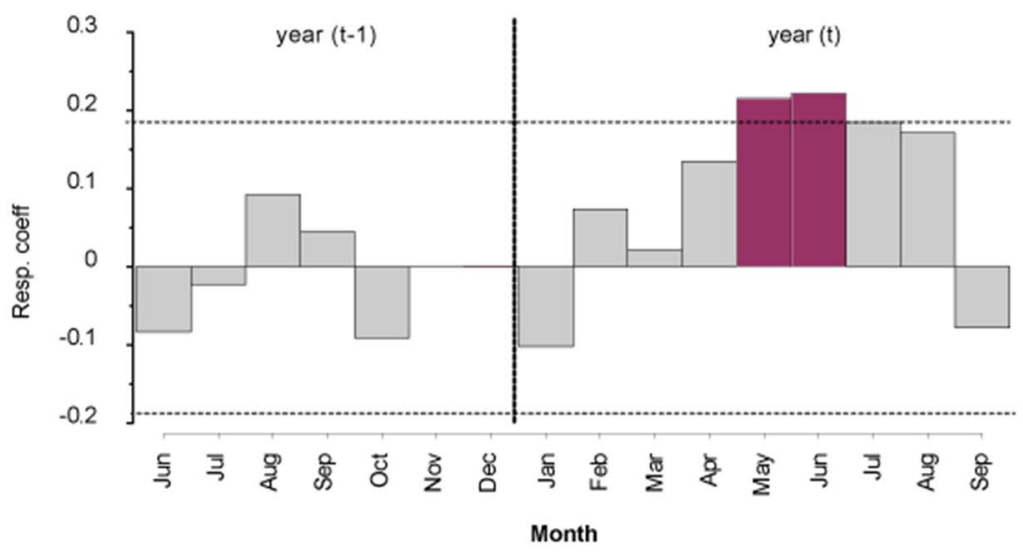

Temp. May (t)
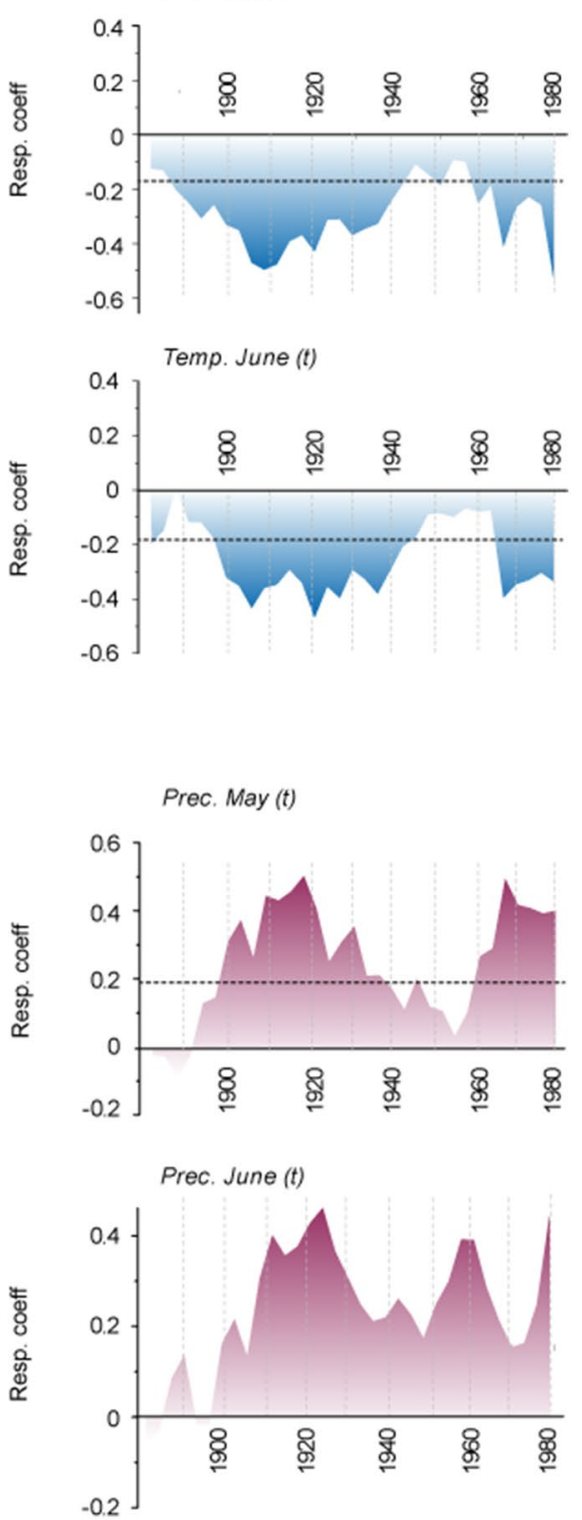

Fig. 7 Correlation function analysis between spline detrended chronologies, monthly mean temperature (a), and monthly precipitation (b), and moving 50-year correlation functions between climate varia-

to be favored by above-average precipitation totals combined with above-average temperatures in November of year $t-1$.

\section{Temporal stationarity of monthly climate correlations}

CFs adequately decipher the year-to-year climate-growth responses of $P$. uncinata at both stands but are, at the same time, unable to detect changes over time. In addition, despite the apparent strength of the observed correlations between climatic parameters and the tree-ring chronologies, they vary in stability throughout the period analyzed. We examined the bles and spline detrended chronologies (c), for the period 1905-2008, at Cirque de Bresson. Dotted lines indicate significant relationships at $p<0.05$

long-term variability of climate-growth relations in ringwidth chronologies using MCFs coupled to the meteorological series from the HISTALP database (Figs. 7b, 8b) and uncovered temporal (in)stability of key climatic variables and growth at both the Cirque de Bresson and La Plagne sites.

The negative correlation of tree-ring widths with May and June temperature in year $t$, as evidenced by the CF analysis has been a common driver of tree growth at Cirque de Bresson over the past 130 years. By contrast, May and June precipitation in year $t$ exhibits a sharply increasing and significant influence on radial growth since 


\section{A Monthly temperatures}
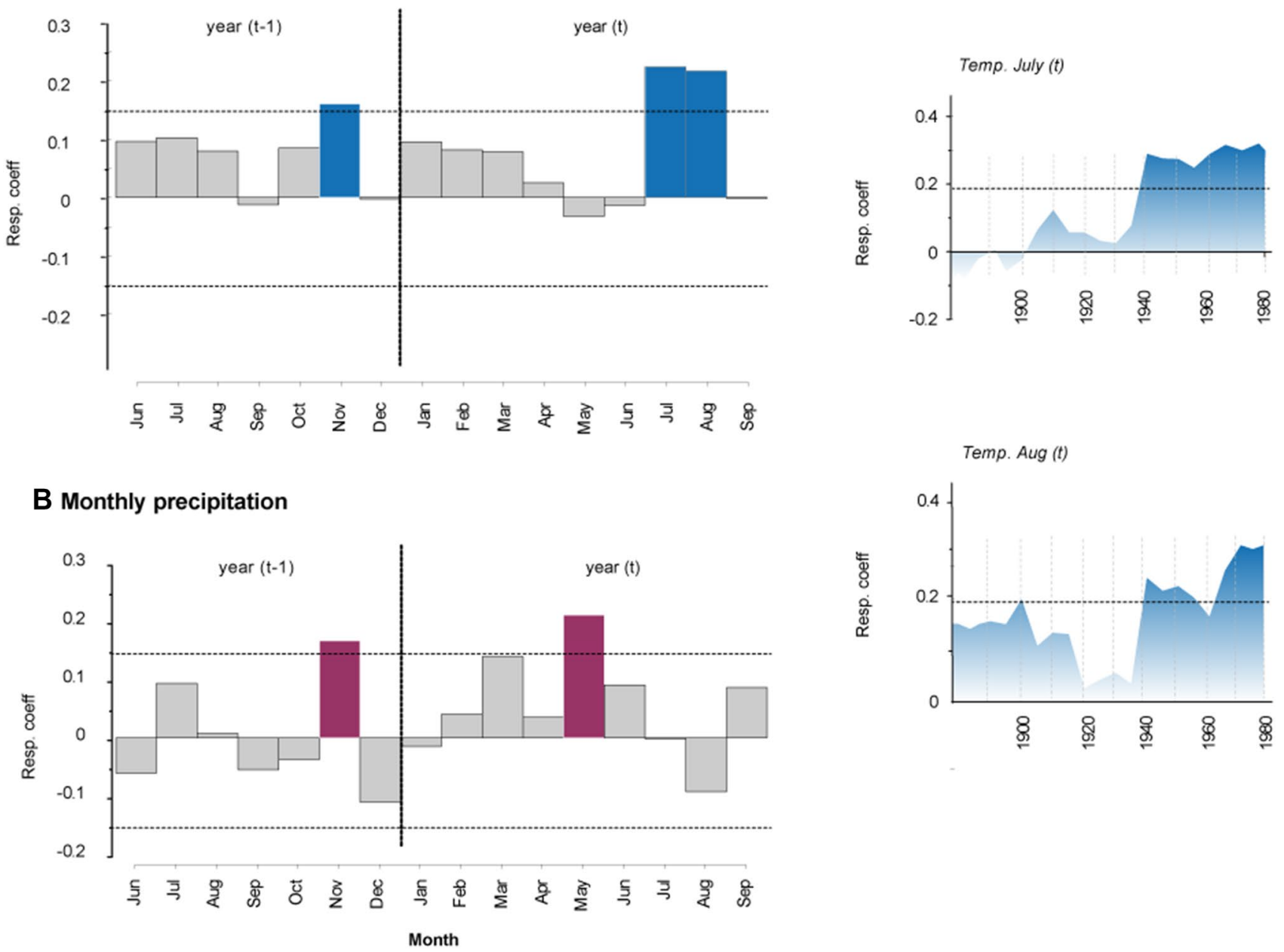

Fig. 8 Correlation function analysis between spline detrended chronologies, monthly mean temperature (a), and monthly precipitation (b), and moving 50-year correlation functions between climate varia-

around 1920. Yet, correlations with precipitation totals (Fig. 7b) are less stable as compared with temperature and tend to be nonsignificant at times.

At La Plagne, positive relations are observed between tree growth and July-August temperatures. The strength of the positive relationship increased in recent decades and was significant ever since the 1940s (Fig. 8b). Similarly, November temperatures in year $t-1$ have been shown to be a significant predictor of radial growth over the past decades, whereas the regression estimates increased as soon as the calibration period ended after the mid-1930s. Significant coefficients of November precipitation totals remained scattered up to the 1960 s, but response coefficients started to exhibit a striking increase since the end of the calibration period in the 1960s. bles and spline detrended chronologies (c), for the period 1905-2008, at La Plagne. Dotted lines indicate significant relationships at $p<0.05$

\section{Analysis of growth trends}

The growth functions obtained with the ARGC standardization (Fig. 9a, c) -maximizing low-frequency informationwere fitted to each tree using the ANN, are shaped close to a negative exponential function, and describe the age-related growth behavior of trees.

The ARGC chronologies from Cirque de Bresson are plotted in Fig. 9a with May-June mean temperatures and precipitation sums (Fig. 9b) using a 10-year low-pass filter. The chronology clearly shows decadal variability with depressed growth in 1920, 1955, 1965, 1975, and $\sim 1990$ and a clear negative trend since the beginning of the 1990s. Decadal ring-width depressions properly coincide with low precipitation totals and positive 

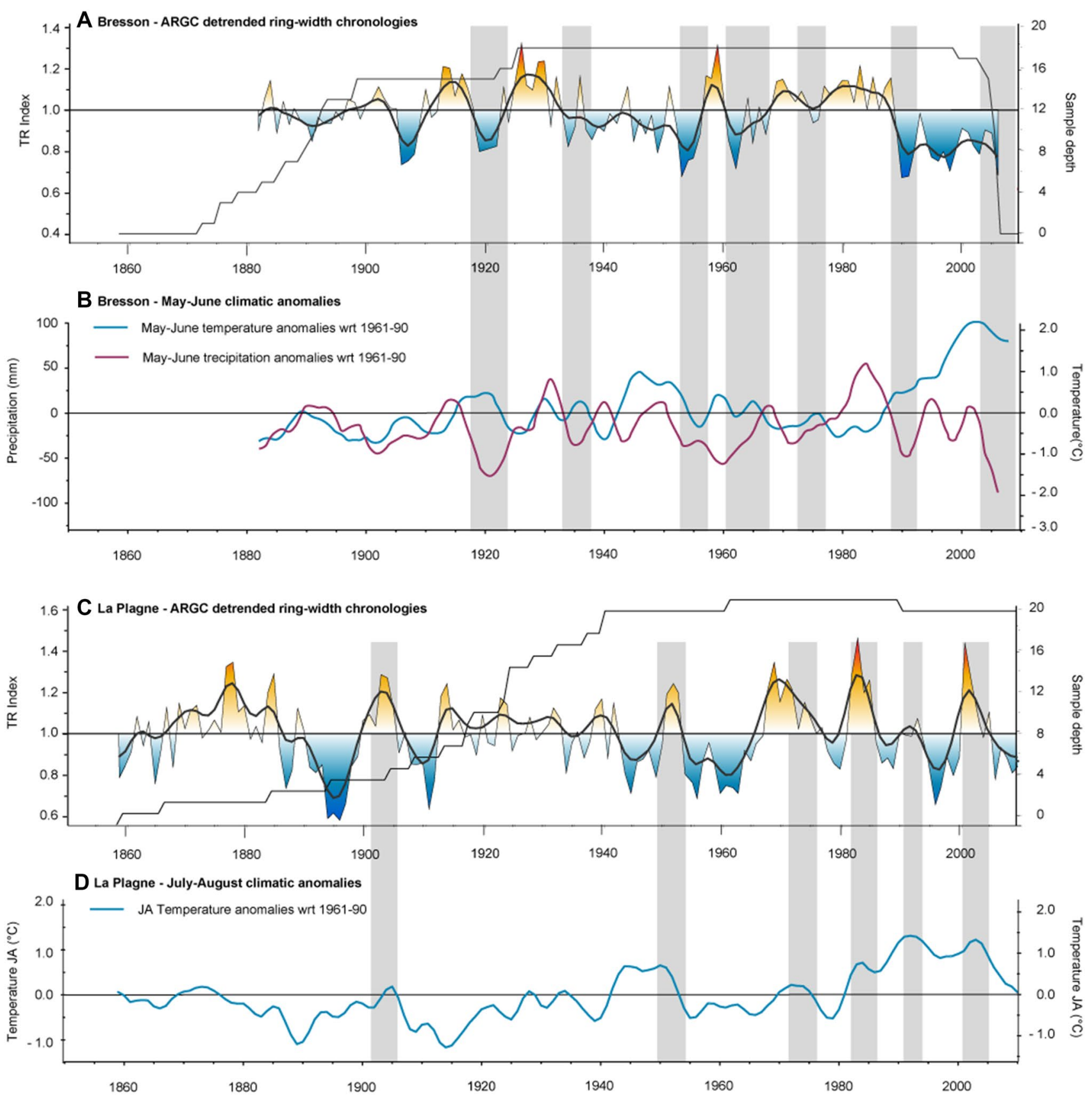

Fig. 9 Comparison of low-pass-filtered ARGC detrended chronologies and key climate variables: 10-year low-pass-filtered Cirque de Bresson chronology (a) and May-June temperature (blue line) and precipitations (green line) (b); 10-year low-pass-filtered La Plagne chronology (c) and July-August temperature (d). Yellow bars empha-

temperature anomalies at the beginning of the vegetative period (i.e., between May and June, Fig. 9b). The decreasing trend in tree-ring width observed since the beginning of the 1990s is of particular interest here and concurs with the increasing occurrence of droughts in May and June. size periods of growth depression coinciding with drought periods at Cirque de Bresson. Pink bars emphasize periods increases in radial growth coinciding with above-average summer temperature at $\mathrm{La}$ Plagne

At La Plagne, growth releases are observed in 1900-1905 , 1920, 1950, 1970, 1985, 1990, and 2005 (Fig. 9c). Large ring widths concur with above-average July-August temperature anomalies in this case, especially since the mid-twentieth century (Fig. 9d). Conversely, summer 
temperatures do not seem to represent a limiting factor for tree growth here.

\section{Discussion}

In this paper, we demonstrate that two relict, low-altitude Pinus uncinata populations growing on scree slopes exhibit very distinct growth patterns to recent climate change. On the avalanche fan at Cirque de Bresson, relict $P$. uncinata trees are highly sensitive to dry conditions such that their growth is affected by low precipitation sums and above-average temperatures at the start of the growing season in May and June $(t)$. By contrast, on the ventilated, cold scree slope at La Plagne, where ground temperatures remain cold even during hot summers, tree growth is correlated positively with temperature anomalies in November $(t-1)$ and in summer (July, August; $t$ ). These differences in growth response to the ongoing warming have major implications for the vitality of trees at the Cirque de Bresson site, and will have even greater implications as global warming continues.

\section{Drivers for radial growth at Cirque de Bresson}

The specific relationship of $P$. uncinata growth at Cirque de Bresson and its sensitivity to dry conditions at the start of the growing season has not been observed previously at timberline sites in the French Alps (Rolland and Schueller 1996; Petitcolas 1998) and, therefore, raises a suite of intriguing questions related to the fate of this pine species in a future greenhouse climate. The negative correlation between tree growth and temperature goes against studies on P. uncinata in the Pyrenees (Tardif et al. 2003) or the French Alps (Rolland and Schueller 1995; Petitcolas and Rolland 1998), where May ( $t$ ) temperature was found to be positively correlated with tree-ring width. By contrast, our findings agree with Affolter et al. (2010), who reported that tree growth of Scots pine (Pinus sylvestris L.) in a dry inner-alpine valley of the Swiss Alps would be strongly correlated with the June Palmer drought severity index (PDSI) at low elevations (<1000 m a.s.l) but that the same signal was missing at higher elevations.

The negative correlation of tree growth at Cirque de Bresson with spring precipitation totals $(t)$ is presumably enhanced by the southern exposure of the slope and shallow soils, thereby exacerbating the water-holding capacity and favoring aridity. As a consequence, trees at Cirque de Bresson are more likely to experience water stress and concomitant decreases in carbon fixation due to stomatal closure (Lebourgeois 2000) and associated reductions in cell turgor, leaf expansion, and synthesis and translocation of auxin (Leal et al. 2008). In that sense, our findings are in concert with results from dry inner-alpine valleys where radial growth has been demonstrated to be driven primarily by spring precipitation for $P$. sylvestris (Oberhuber et al. 1998; Rigling et al. 2002) and by droughts during the growing season for Swiss stone pine (Pinus cembra L.; Pfeifer et al. 2005; Oberhuber et al. 2008). In that context, Anfodillo et al. (1998) reported that soils at timberline in the Italian Alps tend to become physiologically dry during drought years and that above-average temperatures associated with droughts and vapor pressure deficits would have very negative effects on the photosynthesis of $P$. cembra, therefore also limiting stored reserves.

Tree growth at Cirque de Bresson was also limited by dry conditions during summer (August and, to a lesser extent, September; $t-1)$. A negative correlation with drought in previous summer has been reported for other sites in the subalpine belt of the French Alps, namely at the Taillefer (Petitcolas 1998), Queyras, and Briançon massifs (Rolland and Schueller 1996; Petitcolas 1998; Petitcolas and Rolland 1998), and was assumed to be driven by restricted root growth or the depletion of stored reserves (Petitcolas 1998).

In addition, at Cirque de Bresson, depressions observed in radial growth coincide nicely with above-average temperature combined with below-average precipitation sums in May and June $(t)$. Since the 1990s, a strong growth decrease can be observed, and this decrease is by no means attenuated by the repeat occurrence of above-average summer precipitation (as, e.g., between 1995 and 1997 or 2000 and 2003). Drought-induced growth declines similar to those observed at Cirque de Bresson have been reported for other regions during the last decades, also (i) in the Mediterranean area (Martin-Benito et al. 2010; Seim et al. 2014; Tejedor et al. 2017; Sangüesa-Barreda et al. 2019). Comparable observations were also made (ii) at xeric treeline sites of boreal forests (Lloyd and Fastie 2002) or (iii) in forest populations in dry inner-alpine valleys, where mortality of susceptible or less competitive species has increased markedly as a result of direct and indirect impacts of drought stress and higher temperatures (Rebetez and Dobbertin 2004; Bigler et al. 2006; Cailleret et al. 2017).

\section{Drivers of radial growth at La Plagne}

At La Plagne, tree growth is correlated positively with November $(t-1)$ and summer (July, August; $t$ ) temperatures. Results are in agreement with Rolland and Schueller (1996) and Petitcolas (1998), who studied the north-facing populations in the Briançon massif to find positive correlations with temperature in previous autumn (i.e., October and November $t-1$ ). We assume that thermal stress during fall $(t-1)$ could in fact have limited the formation of metabolic reserves and consequently affect radial growth in year $t$, as observed for $P$. uncinata and 
P. cembra at other alpine sites (Rolland and Schueller 1995; Oberhuber 2004; Pfeifer et al. 2005; Gruber et al. 2010). Similarly, Tranquillini (1959) demonstrated that photosynthesis can occur until late October under favorable conditions, i.e., at a time when growth processes are already terminated. By consequence, sugars and carbon stored late in autumn become available at the beginning of the next growing season (Wardle 1971; Baig and Tranquilini 1980), thereby promoting mycorrhizal root growth and favoring maturation of needles, shoots, and buds against the detrimental effects of winter stress (Oberhuber et al. 2008).

At La Plagne, the observed increase in radial growth coincides with above-average temperatures during summer (JA) especially since the 1970 s as reported for $P$. uncinata trees at higher elevations in the Pyrenees (Büntgen et al. 2017). The positive correlation of tree-ring width with summer temperatures is probably reflective of the very specific thermal conditions and air circulation in ventilated scree slopes. In cold scree slopes, the aspiration of warm outside air and the gravitational downslope discharge of air masses in the scree slope body will typically result in significant cooling and low temperatures in the lower parts of the scree (Morard et al. 2008), thus maintaining a cold (if not frozen) soil for much of the spring and summer seasons. At La Plagne, the gravitational discharge of cold and dense air has been shown to prevent ground soil temperature exceeding $6{ }^{\circ} \mathrm{C}$ (Brun et al. 2000); the authors have also illustrated that the cooling is more effective in a warming climate, and likewise during warm days. Whereas ground soil temperatures at $\mathrm{La}$ Plagne will remain below $4{ }^{\circ} \mathrm{C}$ whenever maximum daily air temperature exceed $25^{\circ} \mathrm{C}$, they may reach up to $6{ }^{\circ} \mathrm{C}$ with maximum daily air temperatures in the range of $16-20{ }^{\circ} \mathrm{C}$ (Brun et al. 2000). Paradoxically, increasingly higher summer air temperatures are thus likely to enhance tree growth in the relict $P$. uncinata tree stand at La Plagne as soil temperatures are maintained at a lower level by the chimney effect in this ventilated scree slope. In addition, high summer air temperatures are considered to favor humidification of scree slopes by (i) thawing of interstitial ice due to heat transfer from the surface and aspiration of external warm air in the upper part of the slope; as well as through (ii) a cooling and condensation of warm air during its passage in the cold scree (Morard 2011). The basal part of the La Plagne scree slope is composed of decametric limestone blocks with poor interstitial matrixes and, thus, has a low water storage capacity. As a matter of fact, any increase in moisture content during hot summers may explain the positive correlation observed between the radial growth of $P$. uncinata and summer temperatures.

\section{Conclusions}

Comparison of two relict, low-altitude $(<1300 \mathrm{~m}$ a.s.l.) $P$. uncinata stands in the French Alps shows strong, yet divergent, growth trends and clear evidence of a significant, rapid growth decline on the south-exposed Cirque de Bresson site. At La Plagne, by contrast, growth conditions remain ideal because the cold, ventilated scree slope on which the forest is growing maintains humidity during summer and thus creates very favorable conditions for $P$. uncinata to resist climate warming. Our work is among the first to detail the dendroecological response of relict, low-altitude mountain pine forests to climate change, and to demonstrate how tree-growth relations are susceptible to be impacted by global warming. On the other hand, clear evidence exists for the impact of drier and warmer summer conditions on P. uncinata at Cirque de Bresson over the twentieth century and that drought has increased significantly over the past decades. Our study therefore points to divergent growth trends in relict, low-altitude $P$. uncinata stands in the French Alps, especially since the 1990s. At La Plagne, higher summer temperatures do not affect tree growth, because the cold, ventilated scree slope on which they grow maintains fresh and humid soil conditions, thereby favoring tree growth. This is in stark contrast to the sharp growth decline observed at Cirque de Bresson, where higher temperatures at the beginning of the growing season (May-June) and the related increase in water soil stress hamper tree growth. The sharp growth decline observed at the of Cirque de Bresson since the 1990s represents a pattern that is frequently observed before mortality (Bigler et al. 2006). This evolution raises fear that $P$. uncinata could ultimately vanish from low-elevation refugia, thus also leading to the disappearance of little-represented, high-value ecosystems pushed into the greenhouse trap forever (Grabherr et al. 1995).

Funding Open Access funding provided by Université de Genève.

Open Access This article is licensed under a Creative Commons Attribution 4.0 International License, which permits use, sharing, adaptation, distribution and reproduction in any medium or format, as long as you give appropriate credit to the original author(s) and the source, provide a link to the Creative Commons licence, and indicate if changes were made. The images or other third party material in this article are included in the article's Creative Commons licence, unless indicated otherwise in a credit line to the material. If material is not included in the article's Creative Commons licence and your intended use is not permitted by statutory regulation or exceeds the permitted use, you will need to obtain permission directly from the copyright holder. To view a copy of this licence, visit http://creativecommons. org/licenses/by/4.0/. 


\section{References}

Affolter P, Büntgen U, Esper J, Rigling A, Weber P, Luterbacher J, Frank D (2010) Inner Alpine conifer response to 20th century drought swings. Eur J for Res 129:289-298

Anfodillo T, Rento S, Carraro V, Furlanetto L, Urbinati C, Carrer M (1998) Tree water relations and climatic variations at the alpine timberline: seasonal changes of sap flux and xylem water potential in Larix decidua Miller, Picea abies (L.) Karst. and Pinus cembra L. Ann for Sci 55:159-172

Asta J, Orry F, Toutain F, Souchier B, Villemin G (2001) Micromorphological and ultrastructural investigations of the lichen-soil interface. Soil Biol Biochem 33:323-337

Auer I, Böhm R, Jurkovic A, Lipa W, Orlik A, Potzmann R, Schöner W, Ungersböck M, Matulla C, Briffa K, Jones P, Efthymiadis D, Brunetti M, Nanni T, Maugeri M, Mercalli L, Mestre O, Moisselin J-M, Begert M, Müller-Westermeier G, Kveton V, Bochnicek O, Stastny P, Lapin M, Szalai S, Szentimrey T, Cegnar T, Dolinar M, Gajic-Capka M, Zaninovic K, Majstorovic Z, Nieplova E (2007) HISTALP-historical instrumental climatological surface time series of the Greater Alpine Region. Int J Climatol 27:17-46

Baig MN, Tranquillini W (1980) The effects of wind and temperature on cuticular transpiration of Picea abies and Pinus cembra and their significance in dessication damage at the alpine treeline. Oecologia 47:252-256

Bertinelli F, Petitcolas V, Asta J, Richard L, Souchier B (1993) Dynamic relations between vegetation and soil on cold scree in Southern French Alps (relations dynamiques entre la végétation et le sol sur éboulis froid dans les Alpes françaises méridionales). Rev D'ecologie Alp 2:93-104

Bigler C, Bräker OU, Bugmann H, Dobbertin M, Rigling A (2006) Drought as an inciting mortality factor in Scots pine stands of the Valais, Switzerland. Ecosystems 9:330-343

Biondi F, Waikul K (2004) DENDROCLIM2002: a C++ program for statistical calibration of climate signals in tree-ring chronologies. Comput Geosci 30:303-311

Böhm R, Jones PD, Hiebl J, Frank D, Brunetti M, Maugeri M (2010) The early instrumental warm-bias: a solution for long central European temperature series 1760-2007. Clim Change 101:41-67

Braker O (2002) Measuring and data processing in tree-ring research? A methodological introduction. Dendrochronologia 20:203-216

Briffa KR, Jones PD, Bartholin TS, Eckstein D, Schweingruber HF, Karlen W, Zetterberg P, Eronen M (1992) Fennoscandian summers from $\mathrm{AD} 500$ : temperature changes on short and long timescales. Clim Dyn 7:111-119

Brun JJ, Delcros P, Rovéra G, avec la collaboration de S. Arquès, Corona C, Debarbieux B (2000) Biodiversité des écosystèmes et des paysages en Rhône-Alpes, vers une intégration de la biodiversité dans la gestion durable des milieux en moyenne montagne : l'exemple du Parc Naturel Régional du massif de la Grande Chartreuse. Rapport final du programme fédérateur Environnement du $\mathrm{XI}^{\mathrm{e}}$ Contrat de Plan Etat-Région Rhône-Alpes, Cemagref- Université Joseph Fourier, p 130

Büntgen U, Krusic PJ, Verstege A, Sangüesa-Barreda G, Wagner S, Camarero JJ, Ljungqvist FC, Zorita E, Oppenheimer C, Konter O, Tegel W, Gärtner H, Cherubini P, Reinig F, Esper J (2017) New tree-ring evidence from the Pyrenees reveals western Mediterranean climate variability since medieval times. J Clim 30:5295-5318

Cailleret M, Jansen S, Robert EMR, Desoto L, Aakala T, Antos JA, Beikircher B, Bigler C, Bugmann H, Caccianiga M et al (2017) A synthesis of radial growth patterns preceeding tree mortality. Glob Change Biol 23:1675-1690

Cassagne N, Spiegelberger T, Cecillon L, Juvy B, Brun J (2008) The impact of soil temperature increase on organic matter and faunal properties in a frozen calcareous scree in the French Alps. Geoderma 146:239-247

Cécillon L (2009) Quels indicateurs pour évaluer la qualité des sols forestiers soumis à des contraintes environnementales fortes? $\mathrm{PhD}$ Thesis, University of Grenoble, France, p 215

Cécillon L, Mello NA, Danieli S, Brun J-J (2010) Soil macroaggregate dynamics in a mountain spatial climate gradient. Biogeochemistry 97:31-43

Cook ER (1985) A time series analysis approach to tree-ring standardization. $\mathrm{PhD}$ thesis, University of Arizona

Cook ER, Holmes RL (1984) Program ARSTAN user manual: laboratory of tree ring research. University of Arizona, Tucson

Cook ER, Kairiukstis LA (1990) Methods of dendrochronology applications in the environmental science. Kluwer, Dordrecht

Cook ER, Peters K (1981) The smoothing spline: a new approach to standardizing forest interior tree-ring width series for dendroclimatic studies. Tree Ring Bull 41:45-53

Cook ER, Briffa KR, Meko DM, Graybill DA, Funkhouser G (1995) The 'segment length curse' in long tree-ring chronology development for palaeoclimatic studies. Holocene 5:229-237

Corona C, Guiot J, Edouard JL, Chalié F, Büntgen U, Nola P, Urbinati C (2010) Millennium-long summer temperature variations in the European Alps as reconstructed from tree rings. Clim Past 6:379-400

Corona C, Edouard J-L, Guibal F, Guiot J, Bernard S, Thomas A, Denelle N (2011) Long-term summer (AD751-2008) temperature fluctuation in the French Alps based on tree-ring data. Boreas 40:351-366

Corona C, Lopez Saez J, Stoffel M, Rovéra G, Edouard JL, Guibal F (2015) Impacts of more frequent droughts on a relict lowaltitude Pinus uncinata stand in the French Alps. Front Ecol Evol. https://doi.org/10.3389/fevo.2014.00082

Delaloye R, Reynard E, Lambiel C, Marescot L, Monnet R (2003) Thermal anomaly in a cold scree slope (Creux-du-Van, Switzerland). In: Proceedings of the 8th International Conference on Permafrost, Zurich, pp 175-180

Duret S, Knutti J (2008) Etude fine de la végétation des enclaves boréo-alpines sur éboulis froids de basse altitude. Msc Thesis, University of Neuchâtel, Switzerland, p 129

Esper J, Cook ER, Schweingruber FH (2002) Low-frequency signals in long tree-ring chronologies for reconstructing past temperature variability. Science 295:2250-2253

Etzelmüller B, Hoelzle M, Flo Heggem ES, Isaksen K, Mittaz C, Mühll DV, ødegård RS, Haeberli W, Sollid JL (2001) Mapping and modelling the occurrence and distribution of mountain permafrost. Nor Geogr Tidsskr 55:186-194

Faure C (1968) Feuille de Vif (XXXII-35), Université de Grenoble. Ed, Documents pour la carte de végétation des Alpes. Grenoble

Fritts HC (1976) Tree rings and climate. Academic Press, New York, p 567

Gądek B (2012) Debris slopes ventilation in the periglacial zone of the Tatra Mountains (Poland and Slovakia): the indicators. Cold Reg Sci Technol 74:1-10

Grabherr G, Gottfried M, Gruber A, Pauli H (1995) Patterns and Current Changes in Alpine Plant Diversity. In: Chapin FS, Körner C (eds) Arctic and Alpine Biodiversity: Patterns, Causes and Ecosystem Consequences. Ecological Studies (Analysis and Synthesis), vol 113. Springer, Berlin, Heidelberg. https://doi. org/10.1007/978-3-642-78966-3_12

Gruber A, Pirkebner D, Oberhuber W, Wieser G (2010) Spatial and seasonal variations in mobile carbohydrates in Pinus cembra in the timberline ecotone of the Central Austrian Alps. Eur J for Res 130:173-179

Gude M, Dietrich S, Mäusbacher R, Hauck C, Molenda R, Ruzicka V, Zacharda M (2003) Probable occurrence of sporadic permafrost in non-alpine scree slopes in central Europe. In: Proc. 8th Int. Conf. Perm., Zurich, pp 331-336 
Guiot J, Tessier L (1997) Detection of pollution signals in tree-ring series using AR processes and neural networks. In: Rao TS, Priestley MB, Lessi O (eds) Applications of time-series analysis in astronomy and meteorology. Chapman \& Hall, London, p 413-426

Hock R, Rasul G, Adler C, Cáceres B, Gruber S, Hirabayashi Y, Jackson M, Kääb A, Kang S, Kutuzov S, Milner, A, Molau U, Morin S, Orlove B and Steltzer H (2019) High mountain areas. In: Pörtner H-O, Roberts DC, Masson-Delmotte V, Zhai P, Tignor M, Poloczanska E, Mintenbeck K, Alegría A, Nicolai M, Okem A, Petzold J, Rama B, Weyer NM (eds) IPCC special report on the ocean and cryosphere in a changing climate

Hoelzle M, Haeberli W (1995) Simulating the effects of mean annual air temperature changes on permafrost distribution and glacier size. An example from the Upper Engadin, Swiss Alps. Ann Glaciol 21:400-405

Kneisel C, Hauck C, Mühll DV (2000) Permafrost below the timberline confirmed and characterized by geoelectrical resistivity measurements, Bever Valley, Eastern Swiss Alps. Permafr Periglac Process 11:295-304

Kneisel C, Emmert A, Polich P, Zollinger B, Egli M (2015) Soil geomorphology and frozen ground conditions at a subalpine talus slope having permafrost in the eastern Swiss Alps. CATENA 133:107-118

Lambert A (1967) La formation de glace dans les conduits karstiques, les roches fissurées et les pierriers. Rev Géogr Phys Géol Dyn 2:321-324

Leal S, Eamus D, Grabner M, Wimmer R, Cherubini P (2008) Tree rings of Pinus nigra from the Vienna basin region (Austria) show evidence of change in climatic sensitivity in the late 20th century. Can J for Res 38:744-759

Lebourgeois F (2000) Climatic signals in earlywood, latewood and total ring width of Corsican pine from western France. Ann For Sci 57:155-164

Lloyd AH, Fastie CL (2002) Spatial and temporal variability in the growth and climate response of treeline trees in Alaska. Clim Change 52:481-509

Martín-Benito D, del Río M, Cañellas I (2010) Black pine (Pinus nigra Arn.) growth divergence along a latitudinal gradient in Western Mediterranean mountains. Ann for Sci 67:401. https:// doi.org/10.1051/forest/2009121

Melvin TM, Briffa KR, Nicolussi K, Grabner M (2007) Time-varying-response smoothing. Dendrochronologia 25:65-69

Meynier S, Brun JJ (2018) Humus forms pathways in low-elevation cold scree slopes: Tangel or Mor? Appl Soil Ecol 123:572-580

Molenda R (1996) Zoogeographische Bedeutung Kaltluft erzeugender Blockhalden im außeralpinen Mitteleuropa: Untersuchungen an Arthropoda, insbesondere Coleoptera. Verh Naturwiss Ver Hambg 35:5-93

Morard S (2011) Effets de la circulation d'air par effet de cheminée dans l'évolution du régime thermique des éboulis froids de basse et moyenne altitude. Ph.D. Thesis, University of Fribourg, Switzerland, p 224

Morard S, Delaloye R, Dorthe J (2008) Seasonal thermal regime of mid-latitude ventilated debris accumulation. In: Proceedings of the Ninth International Conference on Permafrost, Fairbanks, Alaska, pp 1233-1238

Morard S, Delaloye R, Lambiel C (2010) Pluriannual thermal behavior of low elevation cold talus slopes in western Switzerland. Geogr Helv 65:124-134

Nicault A, Guiot J, Brewer S, Edouard JL (2010) Preserving longterm climatic changes in standardisation of tree-ring series by the Adaptative Regional Growth Curve (ARGC). Dendrochronologia 28:1-12

Niu F, Cheng G, Niu Y, Zhang M, Luo J, Lin Z (2016) A naturallyoccurring 'cold earth' spot in Northern China. Sci Rep 6:34184
Oberhuber W (2004) Influence of climate on radial growth of Pinus cembra within the alpine timberline ecotone. Tree Physiol 24:291-301

Oberhuber W, Stumböck M, Kofler W (1998) Climate-tree-growth relationships of Scots pine stands (Pinus sylvestris L.) exposed to soil dryness. Trees 13:19-27

Oberhuber W, Kofler W, Pfeifer K, Seeber A, Gruber A, Wieser G (2008) Long-term changes in tree-ring-climate relationships at Mt. Patscherkofel (Tyrol, Austria) since the mid-1980s. Trees 22:31-40

Pawlowski B (1970) Remarques sur l'endemisme dans la flore des Alpes et des Carpates. Plant Ecol 21:181-243

Petitcolas V (1998) Dendroécologie comparée de l'épicéa, du mélèze, du pin cembro et du pin à crochets en limite supérieure de la forêt dans les Alpes françaises: influence de la variabilité macro-écologique. $\mathrm{PhD}$ Thesis, University of Grenoble, p 188

Petitcolas V, Rolland C (1998) Comparaison dendroécologique de Larix decidua Mill., Pinus cembra L. et Pinus uncinata Mill. ex Mirb. dans l'étage subalpin du Briançonnais (Hautes-Alpes, France). Ecologie 29:305-310

Pfeifer K, Kofler W, Oberhuber W (2005) Climate related causes of distinct radial growth reductions in Pinus cembra during the last 200 yr. Veg Hist Archaeobot 14:211-220

Rathgeber C, Nicault A, Guiot J, Keller T, Guibal F, Roche P (2000) Simulated responses of Pinus halepensis forest productivity to climatic change and $\mathrm{CO}$ increase using a statistical model. Glob Planet Change 26:405-421

Rebetez M, Dobbertin M (2004) Climate change may already threaten Scots pine stands in the Swiss Alps. Theor Appl Climatol 79:1-9

Richard L (1970) La végétation des zones froides de l'étage montagnard (cirques de la Plagne et de Saint-Même en Chartreuse). Ann Du Centre D'enseignement Supérieure De Chambéry 8:69-80

Rigling A, Bräker O, Schneiter G, Schweingruber FH (2002) Intraannual tree-ring parameters indicating differences in drought stress of Pinus sylvestris forests within the Erico-Pinion in the Valais (Switzerland). Plant Ecol 163:105-121

Rinn F (2003) TSAP-Win User Reference Manual. Rinntech, Heidelberg, p 262

Rist A, Philipps M, Auerswald K (2003) Undercooled scree slopes covered with stunted dwarf trees in Switzerland - abiotic factors to characterize the phenomenon. In: 8th Int. Conf. Permafrost, Zurich 2003, Extended Abstracts Volume, pp 135-136

Rolland C, Schueller J (1995) Comparaison dendroécologique de trois pinèdes de Pin à crochets (Pinus uncinata Mill. ex Mirb.) dans les Alpes occidentales externes, intermédiaires et internes. Dendrochronologia 13:85-95

Rolland C, Schueller J (1996) Dendroclimatologie du Pin à crochets (Pinus uncinata Mill. ex Mirb.) dans le Briançonnais et le Queyras en fonction des conditions stationnelles. Schweiz Z Forstwes 147:351-363

Rumelhart DE, Hinton GE, Williams RJ (1986) Learning representations by back-propagating errors. Nature 323:533-536

Ruzicka V, Zacharda M (1994) Arthropods of stony debris in the Krkonose Mountains, Czech Republic. Arct Antarct Alp Res $26: 332-338$

Sangüesa-Barreda G, Camarero JJ, Sánchez-Salguero R, Gutiérrez E, Linares JC, Génova M et al (2019) Droughts and climate warming desynchronize Black pine growth across the Mediterranean Basin. Sci Total Environ 697:133989. https://doi.org/10.1016/j. scitotenv.2019.133989

Saulnier M, Edouard JL, Corona C, Guibal F (2011) Climate/growth relationships in a Pinus cembra high-elevation network in the Southern French Alps. Ann for Sci 68:189-200 
Sawada Y, Ishikawa M, Ono Y (2003) Thermal regime of sporadic permafrost in a block slope on Mt. Nishi-Nupukaushinupuri, Hokkaido Island, Northern Japan. Geomorphology 52:121-130

Seim A, Treydte K, Trouet V, Frank D, Fonti PS, Tegel W, Panayotov M, Fernández-Donado L, Krusic P, Büntgen U (2014) Climate sensitivity of Mediterranean pine growth reveals distinct east-west dipole. Int J Climatol 35:2503-2513

Shi F, Yang B, Linderholm HW, Seftigen K, Yang F, Yin Q, Shao X, Guo Z (2020) Ensemble standardization constraints on the influence of the tree growth trends in dendroclimatology. Clim Dyn 54:3387-3404

Sone T (2005) Extra-zonal permafrost and ground air circulation at a slope along the Kanokodam, Oketo town, Hokkaido, Japan. Sec. Europ. Conf. Permafrost., Potsdam, Germanby, Terra Nostra, p 80

Stiegler C, Rode M, Sass O, Otto JC (2014) An undercooled scree slope detected by geophysical investigations in sporadic permafrost below 1000 M ASL, Central Austria. Permafr Periglac Process 25:194-207

Tardif J, Camarero JJ, Ribas M and Gutiérrez E (2003). Spatio temporal variability in tree growth in the central Pyrenees: climatic and site influences. Ecol Monogr 73:241-257

Tejedor E, Saz MÁ, Cuadrat JM, Esper J and de Luis M (2017) Temperature variability in the Iberian Range since 1602 inferred from tree-ring records. Clim Past 13:93-105. https://doi.org/10.5194/ cp-13-93-2017

Tejedor E, Saz MA, Esper J, Cuadrat JM, De Luis M (2017) Summer drought reconstruction in northeastern Spain inferred from a tree ring latewood network since 1734. Geophys Res Lett. https://doi.org/10.1002/2017GL074748

Tranquillini W (1959) Die Stoffproduktion der Zirbe (Pinus cembra L.) an der Waldgrenze während eines Jahres. Planta 54:130-151

Tranquillini W (1979) Physiological ecology of the Alpine timberline: tree existence at high altitudes with special reference to the European Alps. Springer-Verlag, Berlin

United States Department of Agriculture and Natural Resources Conservation Service (USDA) (1999) Soil taxonomy a basic system of soil classification for making and interpreting soil surveys. Agriculture Handbook, vol 436. Soil Survey Staff, Washington, DC

Wakonigg H (1996) Unterkühlte Schutthalden. Beiträge zur Permafrostforschung in Osterreich. Arbeiten aus dem Inst. f. Geogr. Karl-Franzens-Universität Graz, vol 33, pp 209-223

Wardle P (1971) An explanation for Alpine timberline. N Z J Bot 9:371-402

Wicky J, Hauck C (2017) Numerical modelling of convective heat transport by air flow in permafrost talus slopes. Cryosphere 11:1311-1325

Wigley TM, Briffa KR, Jones PD (1984) On the average value of correlated time series, with applications in dendroclimatology and hydrometeorology. J Clim Appl Meteorol 23:201-213

Zacharda M, Gude M, Krause S, Hauck C, Molenda R, Ruzicka V (2005) The relict mite Rhagidia gelida (Acari, Rhagidiidae) as a biological cryoindicator of periglacial microclimate in European Highland Screes. Arct Antarct Alp Res 37:402-408 